\begin{tabular}{rr}
\hline \hline & $81^{\prime} 42$ \\
811.163 .41 & 37 \\
https://doi.org $/ 10.18485 / \mathrm{msc} .2017 .46 .3 . c h 12$
\end{tabular}

Јован М. ЧУДОМИРОВИЋ*

Филолошки факултет

Универзитета у Београду

\title{
О КОНЕКТОРИМА КОЈИМА СЕ СИГНАЛИЗИРА ПРОМЕНА ПРЕДМЕТА ДИСКУРСА
}

\begin{abstract}
У раду се описују конектори којима се у дискурсу обележава промена предмета (,теме”) - a, елем, иначе, него, узгред (буди речено), као и њима блиски изрази - e, е сад(a), што се тиче, кад је реч о. На примерима из корпуса разговорног језика, као и из писаних извора, идентификују се разлике у функцијама појединих конектора, као и њихове стилске специфичности. У закључку коментаришемо резултате и указујемо на могуће теме нових истраживања на које добијени налази упућују.
\end{abstract}

Кључне речи: конектори, промена теме, промена предмета, лингвистика текста, анализа дискурса, семантика, прагматика

\section{1. Увод}

Циљ овог рада је да опише једну класу конектора - оних којима се сигнализира промена предмета дискурса. Тај опис треба да покаже који су типични маркери промене предмета у дискурсу и какве су разлике - формалне и семантичке/прагматичке - унутар те групе.

Под конекторима подразумевамо речи и изразе чија функција није да допринесу пропозиционом садржају исказа чији су део, већ да сигнализирају однос између сегмента дискурса у ком се налазе и сегмента дискурса који му непосредно претходи. Осим тога, иако постоје изузеци, конектори типично имају и следећа два својства: (1) синтаксички су издвојени, што се види по томе што за себе не могу везати енклитике (прозодијски показатељ те издвојености су паузе и/или промена висине/јачине тона у односу на окружење, док се у писању то сигнализира одговарајућеом интерпункцијом); (2) теже да заузму иницијалну позицију унутар сегмента дискурса коме припадају, тј. да се нађу на почетку или што ближе почетку реченице или реплике,

\footnotetext{
"msc@fil.bg.ac.rs
} 
а кад је реч о већим сегментима дискурса, као што је нпр. пасус писаног текста, да се нађу у првој реченици итд.

За ове јединице у лингвистичкој литератури постоји на десетине различитих термина: дискурсни маркери, дискурсни конективи, дискурсне партикуле, прагматичке партикуле итд. (за исцрпан попис различитих термина в. Фрејзер (1999) или Шифрин (2003), а на српском Мишковић Луковић (2006)). У сербокроатистичкој литератури уобичајио се термин текстуални конектор, који је увела М. Велчић (1987). У овом раду користићемо пак термин конектор, који сматрамо прикладнијим јер се конектори, начелно гледано, употребљавају како у писаном, тако и у говореном језику; штавише, има конектора, како ћемо видети и у овом раду, који су карактеристични управо за разговорни језик, док су у писаном далеко мање обични, а то је разлог више да се термином не сугерише како су везани само за графички медијум. Уз све то, термин конектор је и економичније решење од термина текстуални конектор.

Под предметом дискурса подразумевамо његову тему - то је појам или питање којим се обједињује читав садржај неке дискурсне форме, било да je у питању разговор, излагање, извештај, расправа, приповетка итд. Иако је реч тема у општој лексици у овом значењу уобичајенија него предмет, ипак се одлучујемо за термин предмет, јер се термин тема користи и да означи функцију на плану информативне структуре клаузе (тема и рема, уп. Поповић 2004), па таквим избором избегавамо потенцијалне терминолошке неспоразуме.

Наравно, неки облици дискурса не морају бити обједињени само једним предметом, а неки, нарочито ако су дужи, могу имати један општи предмет који се може рашчланити на више потпредмета. Такође, у неком сегменту дискурса основни предмет се може привремено потпуно напустити увођењем дигресије. У свим овим случајевима прелазак с једног на други (пот)предмет по правилу се на неки начин сигнализира - прозодијским средствима у говору, а графичким у писању (белине, посебан слог за наслове и поднаслове и сл.), а у оба медијума га је могуће обележити и различитим конекторима.

Како истиче Фрејзер (1999), конектори којима се сигнализира промена предмета - или, краће, предметни конектори - разликују се од других типова конектора по томе што не имплицирају никакав специфичнији семантички однос између садржаја сегмената које повезују, већ само сигнализирају прелазак с једног предмета на други (отуд их он не убраја у дискурсне маркере, већ у групу тзв. прагматичких маркера, уп. Фрејзер 1999; 2006). За разлику од тога, други типови конектора најављују у каквом је семантичком односу сегмент коме припадају према претходном садржају и очекивањим која из њега проистичу и, по природи ствари, најчешће повезују сегменте који се баве истим предметом. Ово је могуће илустровати и на примеру конектора у српском. Рецимо, супротни конектори (међутим, додуше, пак, напротив итд.) имплицирају да сегмент дискурса у ком се налазе доноси неку противречност, контраст, поништава очекивање које ствара садржај претходног сегмента дискурса итд., док конектори које бисмо условно могли звати саставним подразумевају да се претходни садржај у наставку само проширује садржајем 
који му је сагласан и само га додатно потврђује (такође, поред тога, осим тога и сл.), појачава (итавише, уосталом), елаборира (наиме), егземплификује (на пример, рецимо) изводи закључке из њега или га резимира (значи, дакле, према томе, речју и др.) итд. (в. Велчић 1987; Пипер 2001; Кликовац 2008; Чудомировић 2009; 2015).

Предметни конектори, колико нам је познато, досад у сербокроатистичкој литератури нису били детаљније обрађивани. М. Велчић (1987) не издваја их као врсту, нити се о њима говори унутар неког од издвојених типова. Пипер (2001: 202-203) говори о маркерима иначе и узгред (буди речено) као сигналима завршетка одн. почетка дигресије. У својим истраживањима као маркере промене предмета издвојили смо конекторе елем и него (Чудомировић 2009), тј. $a$ и него (Чудомировић 2015), а у вези са $a$ и предлошке изразе што се тиче + ген. и кад је реч о + лок. (Чудомировић 2015: 235-243; 376-377). Прегледом Разговорног српскохрватског језика (РСХЈ) С. Савић и В. Половине (1989) као израз с овом функцијом издвојили смо и е (cad(a)). То укупно даје седам различитих маркера: $a, e(c a \partial(a))$, елем, иначе, кад је реч о + лок., него, узгред (буди речено), што се тиче + ген.

У наставку рада испитаћемо употребу ових предметних конектора; конкретније, испитаћемо њихов синтаксички статус (да ли су нужно издвојени или не), позицију у којој се реализују, регистар за који су карактеристични, и прецизније одредити њихову прагматичку функцију (нпр. да ли уводи само одређену врсту предмета, нпр. дигресију, или не и сл.).

Корпус за ово истраживање формирали смо на следећи начин. Најпре смо издвојили све конекторе за које се у досадашњој литератури констатује да могу сигнализирати промену предмета, а затим смо примере употребе ових конектора ексцерпирали из текстова на порталу Растко, из онлајн архиве часописа Време и из РСХЈ. Тако издвојене примере затим смо анализирали према параметрима наведеним у претходном пасусу.

\section{2. Конектори којима се сигнализира промена предмета}

\section{1. Конектор а}

Најфреквентнији маркер промене предмета у нашем материјалу јесте конектор $a$. То није необично, јер сви напоредни везници сасвим уобичајено имају и конекторску употребу (тзв. надовезивачки везници, уп. Поповић 2008), а основна функција напоредног везника $a$ јесте да обележи тематски дисконтинуитет, тј. промену теме у две координиране клаузе (в. Чудомировић 2015). Као конектор, $а$ задржава функцију маркера тематског дисконтинуитета (с тим што губи граматичку улогу координатора), а та функција природно се проширује тако да може обележити не само промену теме између две реченице, него и промену предмета на прелазу с једног на други сегмент дискурса (по правилу већи од реченице). Може се, дакле, начелно разликовати конектор $a$ као маркер промене теме на плану информативне структуре 
клауза и конектор $a$ као маркер промене предмета дискурса. Тако у примеру (1) конектор $a$ обележава промену теме на плану информативне структуре реченице (претходна реченица говори о куглама, а наредна о плафону) унутар истог предмета разговора (саговорница О описује саговорнику И хотел у ком је боравио). За разлику од тога, у примеру (2), саговорница С конектором $a$ сигнализира да мења предмет разговора - до тог тренутка предмет разговора била је одећа, а саговорник С својим питањем напушта тај предмет и прелази на нови - новогодишње планове.

(1) О: То је шарениш, а све што нема и метала и дрвета!

И: Претрпано.

О: Очај, то је очај. А замисли шарениш. Рецимо сад гледај трпезарију. Огромне неке кугле, висе као печурке, али огромне, једно метар и по можда / пречника. А плафон је браон, па бели они листови по драперијама. (РСХJ: 151)

(2) В: Не закопчава се. Ја имам исту такву кошуљу, само ... Могу ти рећи да је одлично. Д: Много су лепе!

С: Бојим се да ће ти открити. (смеју се) Ја сам једну дебљу, једну тању. Добро, ако будеш 'тела још ... јави ...

В: Јавићу

(cмеју се)

$\mathrm{C}: \mathrm{E}$, тако да знаш, овај ... отприлике што је боље.

В: Оно што је ...

Д: Мало веће него ...

В: Није важан рођендан / главно да се скупимо.

$\mathrm{C}: \mathbf{A}$ где ћете на Нову годину?

Н: Знаш шта, размишљала сам шта како, ово оно, лево десно. Ја сам Драгани предлагала да буде у кући и на крају // неће бити... У клубу ће бити / тако да нећемо бити код куће. (РСXJ: 125)

Иако је начелно јасна, ову границу у пракси није увек лако повући, јер се некад промена теме на плану информативне структуре клаузе може истовремено сматрати и увођењем новог потпредмета. А то је тако зато што није могуће недвосмислено утврдити који је то најмањи сегмент дискурса који може бити обједињен једним потпредметом. Рецимо, у примеру (1) основни предмет је изглед хотела у коме је боравила саговорница О. Међутим, није јасно колико се тај предмет даље може „дробити”, тј. делити на потпредмете. Могло би се рећи да унутар тог предмета постоји потпредмет - изглед трпезарије. Али да ли би, по истом принципу, требало и унутар тог потпредмета говорити о ужим потпредметима - изгледу кугли, изгледу плафона и изгледу драперија (или листова по драперијама)? Формално, то је сасвим могуће, али се интуитивно чини да нема много смисла дати статус засебног потпредмета садржају који се састоји од једне једине информације. У овом раду не можемо понудити никакво решење за овај проблем, а питање је да ли је то и начелно могуће, јер је сам појам предмета одн. теме неког дискурса у суштини интуитиван, што се види по томе што је неретко на питање шта је тема неког текста може понудити више различитих одговора (нпр. један уопштенији и други конкретнији), који би притом били приближно једнако прихватљиви. А надаље ћемо у овом раду, у недостатку неког боље утемељеног критеријума, сматрати да потпредмет мора обухватити бар једну независну клаузу. 
У дијалозима конектор $а$ често уводи питања, јер је постављање питања један од типичних начина промене (пот)предмета у разговору:

(3) О: Мени није јасно где спавају ове жене. Ова Цеца и она плава, висока, овог жена,...

И: Можда спавају у овој кућици испред.

Д: Да, сигурно.

И: Или спавају у овом ћошку горе. Има једна кућица...

О: Кућица... А где је чика Лаки? У којој је он соби?

(4) В: Уморан сам, куцо.

Јеси гледала цртаћ?

О: Гледала сам цртани. Много је добар.

В: А шта ради бата Мићко?

O: Откуд ја знам. Цео дан сам код баке и деке. (PCXJ: 156)

Иако су сви досадашњи примери из разговорног језика, конектор $a$ као сигнал промене предмета једнако је уобичајен и у писаном језику:

(5) Кочићев хуманизам, хришћанске провенијенције, експлицитан је и у тексту „Тавновање”. На поруку својих Планинаца: „Само реци, па ће се Бања Лука за тили час зацрљенети од нашије шалова и забијелити од нашије гуњева. Нека не мисли врнтави Швабо - шта мисли!”, - утамничени Кочић је „отпоручио да ништа не чине јер” му [sic] ,jе било жао да планинчад остају без отаца својих".

Треба ли рећи да се тако не понашају револуционари?! А у зулумима Симеуна Ђака - где су најдоследније примењенен загонетне речи [...] (П. Лазаревић, „Кочићев хришћански експресионизам"; rastko.rs)

(6) За извесне операције, а пре свега за операцију дељења, неопходно је имати јасан појам о предмету који треба да се дели. Ако не знамо када је Југославија настала, онда не знамо који њен унутрашњи поредак је меродаван. Да ли је она своје најстабилније одређење имала као краљевина СХC, па би онда, како неки данас све отвореније предлажу, конкурсну масу државе требало поделити између Срба, Хрвата и Словенаца, тј. између три најпетентније републичке државе? А уколико би меродаван био АВНОЈ, са својим декларативним признавањем суверености свих југословенских народа, разлаз Југословена морао би имати форму одвајања народа. (3. Ђинђић, „Наивна формула распада”; rastko.rs)

У оба примера се унутар истог ширег предмета - а то је Кочићев хуманизам (5), тј. могући распад Југославије (6) - конектором $а$ обележава прелазак са једног на други потпредмет, то јест, прецизније, са разматрања једног на разматрање другог Кочићевог текста (5) одн. са једног на други могући критеријум поделе Југославије (6).

\section{2. Конектор него}

И него као конектор може обележити промену предмета, као што се види из наредних примера. У примеру (7) Мирко прекида разговор о потрази за гробом Саве Савановића у јарузи да би увео други предмет - како набавити ствари неопходне да се вампир убије. У примеру (8) Раимунд тренутни предмет сматра непријатним, па зато жели да га напусти и најављује нови. У примеру (9) старац прелази са својих савета на захтев да добије храну. А 
у примеру (10) један од учесника у разговору који се препричава престаје говори о заплењеној дроги да би прешао на конкретан предлог.

(7) Кад већ не могоше ништа више докучити од бабе, они се дигоше те одоше. Пошто су изишли на вратнице, рећи ће кмет Пурко:

- Није вајде, људи, баш нам ваља тражити ту јаругу, а?

- Ваља, јакако! - вели чича Мирко.

- Да се смиримо једном! - додаје Ћебо промукло.

- Него[,] где ћемо наћи врана, непочишћена коња и воде аџијазме? - упита Мирко.

- Богами, јест! - рече Пурко. - То ће нам требати.

(М. Глишић, „После деведесет година”; rastko.rs)

(8) РАИМУНД: А сад грађани чувају малу децу, порашће, кажу, мала деца, саградиће нов Хамелн кад овај поједу пацови. Чувају децу к'о очи у глави. А пацови сваки час па по неког чалабрцну.

ВАЛДЕМАР: Што је то одвратно.

РАИМУНД: Аха, баш одвратно. Него, да ми пређемо на веселије теме...

(М. Стојановић, Пацоловач; rastko.rs)

(9) - А куд си се ти запутио овим недоходним путем? - вели старац.

- Па, дедице, идем да окушам срећу.

- Е, синко, на добром си путу, јер ти идеш путем среће. Ако ме узаслушаш, бићеш и срећан и богат. Али има на том путу и великих препрека, мораћеш их савладати. Него, већ три дана ништа нисам јео. Ако ме чиме послужиш, нећу ти одбити.

(„Вилински двор”, народна прича, у: В. Лазовић, Ловаи змајева, пријатељ вилењака; rastko.rs)

(10) Каже да му је онда Беба Поповић рекао како ваља продати у иностранству „неких 700 кила хероина", знаш оног из Комерцијалне банке, заплењеног 1996, што су га Јовица и Раде чували. Легија се, као, ужаснуо, јер се, као, гади дроге, али га је наводно Драгољуб с две речи уверио: „Они су нас бомбардовали осиромашеним уранијумом, а ми ћемо њима дрогу.” Каже и да му је Беба рекао како је та дрога замењена („швић-швић”) и да ниједна држава није луда да се одрекне тих пара (неких тадашњих 65 милиона марака, по београдској уличној цени; на Западу можда дупло више). Него, да ли би он, Командант Легија, пристао да то уради као „државни посао”. Легија каже да му се допала идеја, као „освета малих људи” (за велике паре). (Време, бр. 702)

Иако у основи имају исту функцију, између конектора него и $а$ могу се уочити и неке разлике. Најпре, него обележава нешто изразитији прекид него $a$ - отуд га није могуће заменити са $a$ у примеру (9), у ком садржај који следи непосредно иза конектора нема никакве везе са претходним сегментом дискурса. У осталим примерима нови предмет се уводи питањима одн. предлозима који следе непосредно за конектором, што је ситуација у којој се, као што смо видели, регуларно употребљава и конектор $a$. Ипак, иако је замена могућа, и у тим примерима него је упадљивији сигнал промене предмета, јер се са $a$ може обележити и само промена на плану информативне структуре реченице.

Осим тога, чини се да конектор него имплицира и известан субјективни однос говорника према предмету који се напушта одн. уводи, што је, сматрамо у вези са синтаксичким и семантичким својствима везника него, на којима почива и конекторска употреба коју овде описујемо. Наиме, везник него има специфичну синтаксичку дистрибуцију - налази се у двочланој конструкцији чији први члан мора бити негиран (а ако није, његов садржај се интер- 
претира као порицање неког другог садржаја, уп. Танасић 2012; Чудомировић 2015), док се на семантичком плану садржај другог конјункта разуме као искључујућа алтернатива садржају који се негира у првом конјункту. На основу такве семантике лексема него развија функцију предметног конектора, и то конектора којим говорник имплицира да о претходном предмету више не треба говорити, јер постоји нешто што је важније $((7),(9),(10))$ или пријатније (8), а у сваком случају - сврсисходније ('не треба више говорити о томе, него о овоме').

На крају, него је као предметни конектор карактеристичан за разговор: примери (7)-(9) представљају дијалоге; једино је пример (10) одломак из новинског текста, али не нарочито формалног, при чему је сегмент у ком је употребљено него заправо реконструкција дијалога. И ако би се употребио у монолошком писаном дискурсу, конектор него би му, сматрамо, давао неформални, разговорни тон, а његову употребу у формалном писаном тексту тешко је замислити.

Што се тиче формалних особина, конектор него употребљава се искључиво иницијално и парентетички (синтаксички је издвојен).

\section{3. Конектор елем}

За разлику од конектора као што су а или него, конектор елем специјализован је за посебну улогу - да означи повратак на предмет који је привремено био напуштен (уп. РСАНУ: s.v. елем; Чудомировић 2009). Њиме се, дакле, не може обележити сваки прелаз с предмета на предмет, већ крај дигресије и наставак основног предмета, тј. предмета чији је развој дигресијом био прекинут. Типичан је следећи пример из Матавуљеве приповетке „Амин” - Никола приповеда о путу по планини током ког је сазнао за Васину смрт; саговорници га прекину питањима о његовом односу с Васом, да би Никола, након што на та питања одговори, конектором елем сигнализирао да се враћа на прекинути предмет - догађаје у вези с Васином смрћу:

(11) [КОНТЕКСТ: Никола Шиљчина препричава догађаје у вези са путом по планини и смрћу мештанина Васе.]

- Мени се ражали, јер сам с Васом живио као са рођеним братом, те се вратих с Јовандом...

- Јесте доста војевали заједно, - додаде њеки вршњак Николин.

- Јесте ли, стрико, крали заједно? - запита њеки младић.

- Јесмо, валај, синовче, и доста стоке покрали, и доста сокова појели, бог да га прости! - одговори Никола... - Елем, би што би, Васа сахранисмо и ожалисмо. (С. Матавуљ, „Амин”; rastko.rs)

Такви су и примери (12) и (13). У првом се приповедачево излагање о легенди да су Ошкоп и Пуздрак проадали душу ђаволу мора привремено прекинути да би читаоце упознао са личношћу фра-Анђела, који се ту први пут помиње; након што то учини, приповедач ће се вратити на основни предмет. У другом доктор из тек започетог основног предмета - разлог да позове саговорника у шетњу - прелази у дигресију (у којој се нижу разлози његовог одласка у село), чији крај (и повратак на основни предмет) сигнализира елем: 
(12) [КОНТЕКСТ: У селу Затрнцима настала је легенда да су мештани и побратими Ошкоп и Пуздрак продали душу ђаволу.]

Побратими су знали за то причање и чешће су због тога сеирили. Поњеки пролазник чуо би оваки разговор: „Капитане, познајеш ли тога лупежа што пролази?” Капитан штекне. „Добро је, памтимо га!” вели Ошкоп или Пуздрак, а уплашени Загорац граби даље, крстећи се. Затрњачки парох, фратар фра-Анђел, који је мрзио све што му доноси бригу или одговорност, бјеше људина од педесет година, сав срастао у салу, те је с муком могао отслужити мису, а обамирао би кад би носио причешће каквом болеснику. Коњ фраАнђелов бјеше такође грдосија. Елем, фра-Анђелу дојадише запиткивања и наговијести о ђаволским старцима; особито досадни бјеху намјерници из даљних крајева. (С. Матавуљ, „Ошкопац и Била”; rastko.rs)

(13) Њеколико дана послије тога, дође доктор као обично у кафану, али необично добро расположен. За вријеме наше партије он је пјевушио, добацивао досјетке, пријатељски задиркивао околне, који се, као свагда, наврсташе око биљара.

Послије игре, доктор ме позва у шетњу, с њеким изразом на лицу, који као да је значио: „Има велика новост.” И заиста одмах започе:

- Знате ли шта је ново?

- Да чујем! - рекох, а помислих у себи: доиста ће ми саопштити да се вјерио са племићком!

- Новост је та, - идем да божићујем у село, код својих.

Рекох немарно:

- Па то ће бити лијепо!

- Нијесам видио своје, осим Борила, ово је пета година. А чујем да је стара болешљива, а имам и њеког посла у селу. Елем, све је то за вас споредно, а главно је да вас позивљем као свога госта! (С. Матавуљ, „Доктор Ивановић”; rastko.rs)

По истом принципу, у следећем примеру из новинске колумне аутор започиње основни предмет - држање Бојане Лекић у време затварања Телевизије БК - али га одмах прекида да би подсетио на најважније чињенице из њене новинарске каријере, а затим са елем обележава повратак на основни предмет:

(14) Оне фамозне радиодифузне ноћи (у којој су све краве црне) када је програм БКТВ-а истериван из етра над Србијом уз помоћ полицијског кордона, сви су јасно уочили кога нема у и пред зградом Аероинжењеринга: упадљиво је недостајала Бојана Лекић, такорећи дојучерашња директорка и главна \& одговорна уредница БКТВ-а, дугогодишња РТВ звезда антислобистичког отпора (а и шире), ономад романтично окрштавана као „икона независног новинарства”, сада у заслуженој пензији. Мислим, у пензији у статусу иконе, не у статусу звезде и осталог...

Елем, било је ових дана кулоарског и јавног запиткивања „куд ли се деде Бојана”, а било је богме и оних који су били ради да тим поводом нешто и одговоре [...] (Време, бp. 800)

Наведени примери међу собом се разликују по карактеру дигресије. У примеру (11), рецимо, место почетка дигресије јасно се може идентификовати - она се уводи питањима које постављају Николини саговорници, препознаје се као прекид тренутног предмета и очекује се да ће се тај предмет касније наставити. Исто тако, у примеру (12) дигресија почиње увођењем фра Анђела у приповедање; пошто је реч о новом лику. Међутим, у друга два примера тешко је недвосмилено одредити место у дијалогу одн. тексту на ком дигресија почиње. У овим примерима, заправо, дигресија се не уводи „одједном”, као засебан потпредмет / споредни предмет, већ настаје 
постепеним развијањем, разрађивањем основног предмета у правцу којим се целокупан дискурс удаљава од оног што говорник или говорници сматрају његовим главним циљем.

Тако се у примеру (13) разлози докторовог одласка у село - није дуго видео своје, мајка му је болесна, има и другог посла тамо - природно надовезују на информацију да он намерава да тамо иде, а његов саговорник (као ни читаоци приповетке) то место не препознају као промену у смеру разговора нити као некакав тематски скок или прекид. Тек кад говорник употреби маркер елем и настави исказ, постаје јасно да су за њега и његове комуникативне намере детаљи о стању у селу заправо споредни. Овде, дакле, није реч о промени предмета у правом смислу, већ пре о томе да унутар основног предмета постоје различити токови или елементи којима треба посветити пажьу, па се конектором елем сигнализира да су управо изнесене информације, иако у оквиру основног предмета, споредне у односу на садржај који следи и који треба третирати као главни ток дискурса. Слично важи и за пример (14) - аутор сматра да је потребно подсетити на важне моменте из каријере Бојане Лекић, али конектором елем показује да је то ипак пратећи елемент, „рукавац” у развоју основног предмета који је прерастао у дигресију, па је потребно јасно обележити повратак на његов магистрални правац.

Из свих наведених примера види се да је конектор елем увек синтаксички издвојен, а појављује се у иницијалној позицији. У нашем материјалу нема потврда за другачији положај, али померање из иницијалне у постиницијалну позицију у примерима које смо навели показује да ни постиницијални положај није увек неприхватљив, премда је знатно ређи (уп. 'Бu, елем, што би..; Фра-Анђелу, елем, дојадише запиткивања...; Све је то, елем, за вас споредно...; Било је, елем, ових дана и кулоарског запиткивања...).

\section{4. Конектор иначе}

Док конектор елем обележава крај дигресије, конектор иначе обележева њен почетак: ${ }^{1}$

(15) У питању је нарочити монолитни систем градње - бетонски панели се слажу као домине, а потом се заливањем бетоном повезују у целину. Сваки панел настаје тако што се у мултифункционални алат лије бетон, еколошка изолација, поставља оквир за прозор, радијатор и арматура. Појединачни алат, који је налик на калуп, кошта око 6000 евра, тежи близу две и по тоне, а највећи део би се, по плану овог иноватора, производио у Србији. За изградњу стана од 75 квадрата потребно је око 60 оваквих алата, док би са њих 1000 било могуће изградити око 15 станова дневно. Иначе, Николићу је као инспирација за патент послужио традиционални принцип градње српском талпом.

Поред брзине приликом извођења радова, ова иновација је револуционарна и због својих изузетних еколошких одлика те и велике економичности. (Време, бр. 1051)

(16) После погибије кнеза Михаила власт у Србији приграбио је министар војске, Миливоје Петровић Блазнавац, за кога се тврдило да је био незаконити син кнеза Милоша. Раније је био огорчени противник Обреновића и као врло млад човек учествовао је у

${ }^{1}$ Пипер (2001: 202-203) наводи да иначе обележава крај, а не почетак дигресије, али ми за такву употребу нисмо нашли потврде. 
бунама против њих, а онемогућио је 1848. год. њихово искоришћавање народног устанка. Иначе се истакао као добар и храбар борац у Книћаниновој војсци против Мађара. После Милошева повратка био је затворен и бачен у немилост, али се иза његове смрти, заузимањем И. Гарашанина, који је имао доста сличан политички пут, нашао поново на првим местима. Вешт, окретан, и са доста способности, он је знао да се дигне до министарског положаја и да се одржи на њему, захваљујући разним утицајима. После Михаилове смрти он се, брзо и одлучно, ставио на чело војске и помоћу ње одмах дао извикати за новог кнеза младог четрнаестогодишњег Милана (рођеног 10. августа 1854.), унука Милошева брата Јеврема. (В. Ћоровић, Историја Срба; rastko.rs)

Проналазачева инспирација (15) одн. Блазнавчево ратничко искуство из 1848. (16) нису део основних предмета - а то су функционисање и намена Николићевог патента одн. Блазнавчев успон у војној и политичкој хијерархији - што се сигнализира конектором иначе. Лексема иначе у својој основној употреби модификује садржај клаузе чији је структурни део, а њена семантика припада временско-условном континууму (уп. Данас је на терену, а иначе је у канцеларији; Морам платити рачун, иначе ће ми искључити струју и сл.) - означава реалне или хипотетичке околности супротне онима у вишој клаузи или претходном конјункту ('у друго време', 'у супротном случају'). На таквој семантици почива и иначе као предметни конектор - уводи садржај који би био основни предмет у неком другом дискурсу или у некој другој прилици, док у конкретном случају представља мање важну информацију. А од лексеме иначе у основној употреби конектор иначе разликује се и по томе што је типично синтаксички издвојен, премда је могуће да остане укључен у структуру клаузе, као што показује пример (16).

Конектор иначе често обележава споредни садржај сасвим малог обима, који би се пре могао окарактерисати као узгредна напомена или податак него засебан предмет и који, на синтаксичком плану, чак не мора ни бити исказан клаузом, него апозитивном синтагмом:

(17) У уторак увече, око 19 часова, у центру Пожаревца одиграла се мучна сцена о којој читав град, иначе родно место председника Милошевића и његове супруге Мирјане Марковић, шапуће и дан касније. (Време, бр. 487)

\section{5. Конектор узгред (буди речено)}

С истом функцијом као иначе може се употребити и конектор узгред (буди речено):

(18) Тако ће, на парадоксалан начин, притисак сељака за исплату пшенице обезвредити цену пшенице - па је њима теоријски свеједно - или да пшеницу дају у пола цене, или да им она буде исплаћена у новцу чија је вредност преполовљена. (Узгред буди речено, изјава генерала Павковића да држава дугује војним резервистима око милијарду динара лепо илуструје цену војне „победе” на Косову - која је само по основу војничких дневница однела пола овогодишње жетве.)

При свему томе ваља се на известан начин „супротставити” оцени да је после НАТО бомбардовања индустрија порушена, али је зато наша перспектива у аграру који је очуван. Пољопривреда није уништена НАТО бомбама, али је пауперизована мерама економске политике (неко је морао платити десетогодишње војевање). (Време, бр. 446) 
(19) проф. Радован Лалић пише: "... песма Бранку Радичевићу не може, по нашем мишљењу, бити увршћена међу Његошева дела. Ту је песму први пут објавио Милош Мартиновић 1908. године у дубровачком часопису Сpђ [...] Ништа више Мартиновић о тој песми не говори. Као што се види из овога, његова је аргументација врло слаба: као доказ за своје тврђење он употребљава један текст чију аутентичност такође треба доказати. Узгред буди речено, Мартиновић овде приписује Његошу један мотив који ниједан познавалац Његоша не може узети озбиљно; ако је Његош спевао песму Бранку Радичевићу, онда то свакако није учинио само због његовог порекла, ма какво оно било. Цео Мартиновићев чланак иначе написан је некритично и у једном тону који нимало не улива поверење. Нема, дакле, никаквих поузданих доказа да је песма Бранку Радичевићу Његошева; ни стил и метар у њој нису Његошеви. Стога сматрамо да би било неправилно укључити је међу његове списе.” (М. Сибиновић, „Његошеве песме о песнику”; )

(20) Епизода почиње тиме што се учитељ Лај разболи, а његов пријатељ Ли долази да га посети и затиче жену и децу да плачу. - Ш-ш, тише, немојте реметити процес преображаја - каже им он. И затим наслонивши се на врата каже свом пријатељу који куња: - Како је чудесан Творац (Tso-wy che)! Шта ли ће од тебе да начини касније? Можда јетру пацова, или ножицу неке бубе? (Узгред, Творац овде по већини тумача означава имперсоналне снаге природе или начело таоа, а у то време није још персонализован у небесника - m'иен - као што се то догађа касније у таоизму, али би и тумачење у духу античког грчког демијурга било легитимно). На то му болесни Лај каже.

У свим примерима конектор узгред (буди речено) могао би се заменити са иначе, али се чини да би он, за разлику од конектора иначе, увек морао бити синтаксички издвојен, не само у дужој (узгред буди речено) него и у краћој варијанти (узгред) (уп. *Узгред је Павковићева изјава илустрација војне ,, победе...; *Узгред је Мартиновић овде приписао...; *Узгред се Твораи овде сматра...). Енклитику, дакле, може везати само прилог узгред, док с конектором узгред то није случај.

\section{6. Изрази који су семантички/функичионално блиски предметним конекторима}

\subsection{1. Што се тиче и кад је реч о}

Посебан статус међу јединицама о којима говоримо имају предлошки изрази што се тиче + ген. и кад је реч о + лок. Наиме, ови изрази се, формално гледано, не могу сматрати конекторима, већ улогу конектора може играти само читава конструкција чији су они део. Другим речима, у примерима типа Што се тиче другог захтева, сматрамо да је он оправдан, јер... и сл. прелазак на нови потпредмет сигнализира се читавом конструкцијом што се тиче другог захтева, а не само изразом што се тиче, који, као ни било који предлог или предлошки израз, није ни могуће употребити самостално. Но ни целу конструкцију такође није могуће сматрати конектором, јер она има свој пунозначни део који варира од случаја до случаја. Реч је заправо о томе да је у дискурсу уместо конектора, у истој улози, могуће употребити различите изразе, синтагме, па и клаузе са пунозначним елементима; такве конструкције могу служити само томе да сигнализирају однос сегмента који следи према оном који му претходи, а могу истовремено и доприносити 
садржају дискурса. Кад говоримо о предметним конекторима, њихову улогу могу имати разни искази попут Да пређемо на следеће питање, Да кажемо нешто о једном другом проблему, Вратимо се накратко на претходну тему, Слушајте ову причу, Ја бих се осврнуо на оно о чему смо раније говорили итд. У овакве изразе спадају и сви они са што се тиче и кад је реч о. Како је њихов број, као и број исказа попут оних које смо малочас навели, практично неограничен, нема много смисла пописивати их. С друге пак стране, предлошки изрази што се тиче + ген. и кад је реч o + лок. јесу функционалне јединице које служе да, у конструкцији са пунозначним делом који их допуњује, уведу нови предмет, па сматрамо да је оправдано осврнути се на њих тамо где се говори о предметним конекторима, без обзира на то што немају статус конектора, слично као што се, на пример, у вези са одређеним типом зависних клауза могу разматрати и предлошко-падежне конструкције које имају исту или сличну семантику.

Конструкције са изразима што се тиче и кад је реч о сигнализирају промену предмета, али је та њихова функција ограничена на један посебан случај, за који, колико нам је познато, није специјализован ниједан конектор. Овим конструкцијама се, наиме, по правилу уводи потпредмет који је претходно у дискурсу или експлицитно најављен или се, чак и ако није најављен, може очекивати. У овом погледу типична су следећа два примера са изразом што се тиче:

(21) Кругу критско-микенских симбола припада и представа „божанског ока” које је представљено на неколико вучедолских ваза, као и фигура једне мале столице (трона) израђене од печене земље.

Троугао с унутра затвореним оком непосредно намеће посматрачу свој симболичан смисао. На једном прстену из Вафија приказано је изнад сцене аграрног култа и једно „божанско око” у слободном простору. Сличне представе ока налазе се и на египатским надгробним стелама [...]

Што се тиче глиненог модела столице, њена култна измена је несумњива [...] (Д. Срејовић, Искуства прошлости; rastko.rs)

(22) У позоришну уметност Јовановић најпре улази као критичар и то врло млад. Са осамнаест година почиње да сарађује у Малом журналу, дневном листу без упадљиве страначке боје и широког информативног спектра. [...] Прву, четворочинску драму Тако рече Заратустра, предао је на анонимни конкурс Матице српске, 1903, као тек свршени матурант, а 1907, за само два дана написао је Kapujepy, комедију у три чина, и њоме је, по свему судећи, завршио своју позоришну пустоловину. У међувремену настали су његови најуспешнији комади сродних, типично тематских наслова и готово трилогијског карактера: Наш зет, Наши очеви и Наши синови. [...]

Што се тиче званичне критичке процене Јовановићевих драма, и она је била у знаку парадокса [...] (М. Миочиновић, „Предговор” Изабраним драмама В. М. Јовановића Марамбоа; rastko.rs)

У примеру (21) помињу се два археолошка артефакта, да би се аутор затим усредсредио на интерпретацију првог од њих - представу „божанског ока". Отуд читалац може очекивати да ће, по завршетку те интерпретације, као наредни потпредмет, уследити опис и интерпретација глинене столице. Аутор то и чини, а прелаз на тај најављени потпредмет сигнализира конструкцијом са изразом што се тиче. Слично је и у примеру (22), с једном раз- 
ликом: у њему критичке процене Јовановићевих драма нигде у претходном тексту нису експлицитно најављене као потпредмет који треба очекивати, али се на основу општег знања, тј. на основу законитости жанра коме текст припада, зна да би се у њему морало наћи места за приказ односа критике према Јовановићевом делу. Зато се такав потпредмет сматра очекиваним, иако нигде није експлицитно најављен. Примери (23) и (24) илуструју одговарајуће случајеве са изразом кад је реч о:

(23) У појединим религијама налазимо различита схватања смрти, а често се и унутар исте религије могу наћи различита схватања смрти. Овде ћемо изложити четири схватања смрти у различитим религијским традицијама, која бацају различито светло на смрт. Ако се узму у обзир приближне старости појединих традиција, вероватно је схватање у Старом завету најстарије (ако се претпостави да је оно старије од VI века пре н. е.). Будистичко и таоистичком схватање су приближно из истог периода (око III в. пре н. е.), док је схватање хиндуизма (у Махабхарати и пуранама) најмлађе (крај старе и почетак наше epe). $[\ldots]$

Кад је реч о таоизму, треба имати у виду да постоје одређене разлике између таоизма као филозофије и религије, посебно у каснијем развоју (почев од првих векова наше ере), кад се јавља идеал бесмртника. Овде ћемо се ограничити на таоистичку идеју рециклирања, која се - како смо већ рекли - јавља и у старозаветном начелу „прах-праху” и у будистичком „протоку-појавности.” (Д. Пајин, „Религијско и еколошко значење смрти”; rastko.rs)

(24) Вашингтон верује да ће кандидат демократске опозиције Војислав Коштуница на председничким изборима 24. септембра добити више гласова од садашњег председника СРЈ Слободана Милошевића, али да ће власт у Србији учинити све да покраде изборе; [...]

ИЗБОР ЈЕ ВАШ: Међутим, основни став који је ношен приликом сваког разговора јесте да су предстојећи избори ствар српског народа који ће сам изабрати хоће ли кренути путем демократије или наставити путем деспотије, да ли му је дража Европа и просперитет или сиромаштво и изолација. [...]

БУШ ИЛИ ГОР: Кад је реч о предстојећим америчким изборима, односно о томе какве би могле бити разлике у америчкој политици према СРЈ у зависности од тога победи ли Буш или Гор, чули смо од свих без разлике да ниједан од могућих председника сасвим сигурно неће имати никакве контакте с Милошевићевим режимом, а да ће америчке трупе остати на Косову, као и у Босни до даљег, без обзира на исход америчких избора. (Време, бр. 507)

У вези с овим изразима треба приметити да конструкције с њима немају нужно конекторску улогу, већ могу бити укључене у структуру клаузе, а по значењу и функцији блиске конструкцијама типа у вези сa + инстр., o + лок., у зависности од конкретног контекста. Може се претпоставити да је оваква њихова улога примарна, а да се из ње, издвајањем конструкција с овим изразима из структуре клаузе у иницијалној позицији, развила конекторска употреба:

(25) То је, отприлике, дилема која се одмах јавља кад је реч о односу криминала и паравојних формација почетком деведесетих година прошлог века. Једно с другим иде нераздвојно. (Време, бр. 1315)

(26) Ваља додати и неколико напомена о транскрипцији, пре свега што се тиче примене постојећих правила у пракси. (Одбор за стандардизацију српског језика, „Закључак бр. 12"; rastko.rs) 
Како се види, сви примери су из новинских или научних/академских текстова, а примера из разговорног језика (било из аутентичних свакодневних разговора, било из дијалога у књижевним текстовима) нема, што указује на то да су конструкције са изразима што се тиче или кад је реч о карактеристични за писани језик, и то, чини се, формални писани језик. Ово није необично - будући да уводе потпредмет који је претходно најављен (и који подразумева да обично постоји више потпредмета истог реда), они ће се појавити пре свега у оним облицима дискурса који су већег обима, претежно монолошки и за које је потребно да буду јасно и прецизно структурирани, а то су различити облици академског, медијског или административног дискурса.

\subsection{2. $E$ и е $\operatorname{cad}(a)$}

У свакодневним, неформалним разговорима, промена предмета често може бити обележена речју е или спојем е сад. Узвик одн. експресивна речца $е$ има многобројне функције - од дозивања до исказивања различитих субјективних/емотивних ставова (уп. значења у РСАНУ: 1. при дозивању; 2.а. при исказивању задовољства, усхићења, дивљења; 2.в. при изражавању злурадости, у ликовању; 2.г. при вајкању, жаљењу на нешто или због нечега; 3.а. при исказивању незадовољљства [...]; 4.а. при подстицању, бодрењу; 4.д. при категоричком одбијању или одрицању нечега; 5.а. при потврђивању властитог ранијег исказа [...]; итд.). Чини се да у свим овим употребама ова речца/узвик служи да садржај који следи обележи као посебно значајан и да је та компонента битна и за њену конекторску улогу. У следећем примеру из РСХJ саговорница 3 користи га да у разговор уведе нови предмет:

(27) В: Право да ти кажем сад могу и ја да се бацим мало у јурњаву, по целом Београду ради белих сандала.

3: Ја имам неке еспадриле које ћу да оперем тако, па ће ваљда бити светлије драп боје ако ми баш устреба ... и без нових ...

3: Хоћете пића?

Д: Доста бре! / Види кол'ко сипа.

В: Нећу, хвала.

3: $\mathbf{E}$, како ме Борислав данас изнервирао...

В: Што? (РСХJ)

Конекторску улогу ове речи није лако раздвојити од њене употребе као општег маркера експресивности. У наведеном примеру, рецимо, може се тврдити да е служи да изрази емотивни однос говорника према садржају који следи (уп. значење 3.а. из РСАНУ у претходном пасусу). Да оваква идеја има смисла, показује то што би се у таквој функцији $e$ могло употребити и да у наставку реплике нема никакве промене предмета (уп. нпр. E какви сте то гости кад ништа нећете!). Међутим, помоћу е се може сигнализирати промена предмета и тамо где се не изражава емотивни однос говорника према садржају који следи (уп. нпр. Е да вам причам сад нешто друго). У наведеном случају се, дакле, обједињују две различите функције - изражава се емотивни (негативни) однос према садржају који следи и сигнализира се 
прекид у предметној структури разговора. Ипак, у нашем материјалу налазимо само један пример за $e$ које уводи нови потпредмет а да притом нема и експресивну функцију:

(28) Б: Миле и он, овај Миланче, онај / Миле. ... само нису увек седели заједно ... и дошла Зори [sic] поздраве се они и са Зором све скупа .. и овај, то вече, они тако с тим женама били. $\mathbf{E}$ треће вече ми идемо у дискотеку са овим друштвом / нашим и видимо њих двојицу. Они седе у том дискаћу, знаш / седе / тамо / гледају ... (РСХJ)

Позиција овог маркера је увек иницијална, а синтаксички је издвојен.

Спој $e$ и сад најчешће није експресиван и примарно служи да уведе сегмент дискурса којим се износи садржај који се доживљава као нека врста алтернативе претходном садржају (алтернативног развоја догађаја, алтернативне аргументације итд.), што је и основна функција конектора сад (уп. Чудомировић 2009). Спој е и сад може, међутим, у разговору обележити промену перспективе или активности, којом се уводи нови потпредмет, као у следећем примеру разговора између доктора и пацијента:

(29) Д: Ммммхм, да. Кажи, је л’ ти знаш од чега болујеш? Јеси до сада сазнао шта је и како је, Је л' имаш представу о томе шта је то?

П: Паа - јааа нешто - не знам - мислим, нешто у леђима прикљештено, живац, не знам, мислим, уопште не знам//

Д: Ммхм. (узима снимак, окреће га према светлу и гледа у њега) $\mathbf{E}$, сад види. Ова миографија што је рађена је то доста показала. Показала је да постоји укљештење живаца и да се, највероватније, ради о дизању те рскавичасте плочице, тог, што кажу пацијенти, дискуса. Јеси чуо за то?

П: Паа чуо сам. ${ }^{2}$

Овде се, дакле, не може говорити о промени предмета у правом смислу - доктор и пацијент остају у оквирима истог предмета, али се усредсређују на снимак и оно што он показује. Маркером е сад доктор скреће пажњу саговорника на овај нови потпредмет. Слично томе, у следећем разговору саговорница Б говори о виђању са познаницима Милетом и Миланчетом на летовању, а изразом е сад уводи нову епизоду у тој причи (прву реплику већ смо навели у примеру (28)):

(30) Б: Миле и он, овај Миланче, онај / Миле. ... само нису увек седели заједно ... и дошла Зори [sic] поздраве се они и са Зором све скупа .. и овај, то вече, они тако с тим женама били. Е треће вече ми идемо у дискотеку са овим друштвом / нашим и видимо њих двојицу. Они седе у том дискаћу, знаш / седе / тамо / гледају ...

3: Лове, а?

В: Нормално.

3: Ово било само један дан ...

Б: И видим ја ... Идем да виде они мене / али ми се направимио луди и ништа. / $\mathbf{E}$, сада пошто смо се тако испуцали треће вече се поново сретнемо у градској кафани, дал' је било вече или преко дана / и приђем ја Миланчету и кажем [...] (РСXJ)

\footnotetext{
${ }^{2} \mathrm{У}$ транскрипцијама из PCXJ зарез није коришћен на начин како се иначе користи у транскрипцији разговора - да означи незнатно подизање интонације карактеристично, на пример, за набрајање - већ као „уобичајен знак интерпункције” (в. Савић/Половина 1989: 87), па у примерима попут $e$, сад и $e, c a d a$ није нарочито релевантан, јер није јасно да ли треба да означи кратку паузу или служи да одвоји партикулу од наставка, што се у писаном тексту често чини.
} 
Резултате анализе сажето приказујемо у следећој табели.

\begin{tabular}{|c|c|c|c|c|}
\hline МАРКEP & Издвојеност & ПозицијА & ПРАГМАТИЧКА ФУНКЦИЈА & $\begin{array}{l}\text { РЕГИСТАРСКА } \\
\text { ОБЕЛЕЖЕНОСТ }\end{array}$ \\
\hline \multicolumn{5}{|c|}{ К О Н Е К Т ОР И } \\
\hline $\mathrm{a}$ & + & само И & Сигнализира прелазак на нови предмет. & неутралан \\
\hline него & + & само И & Сигнализира прелазак на нови предмет. & $\begin{array}{l}\text { типичан за разговор; у } \\
\text { писању доноси разго- } \\
\text { ворни тон }\end{array}$ \\
\hline елем & + & И, (П) & $\begin{array}{l}\text { Сигнализира крај споредног предмета / дигресије и повратак } \\
\text { на основни предмет, одн. крај споредног аспекта главног пред- } \\
\text { мета и повратак на његов основни ток. }\end{array}$ & $\begin{array}{l}\text { типичан за разговоре, } \\
\text { неформалан; у писању } \\
\text { доноси разговорни и } \\
\text { неформални тон }\end{array}$ \\
\hline иначе & $(+)$ & И, П & $\begin{array}{l}\text { Сигнализира почетак споредног предмета / дигресије или уз- } \\
\text { гредне напомене унутар основног предмета. }\end{array}$ & неутралан \\
\hline
\end{tabular}




\begin{tabular}{|c|c|c|c|c|}
\hline $\begin{array}{l}\text { узгред } \\
\text { (буди речено) }\end{array}$ & + & И, П & $\begin{array}{l}\text { Сигнализира почетак споредног предмета / дигресије или уз- } \\
\text { гредне напомене унутар основног предмета. }\end{array}$ & неутралан \\
\hline \multicolumn{5}{|c|}{ Изрази семантички/функционално блиски конекторима } \\
\hline што се тиче & + & И & \multirow{2}{*}{$\begin{array}{l}\text { Сигнализира почетак потпредмета који је претходно у дискур- } \\
\text { су експлицитно најављен или га треба очекивати на основу } \\
\text { општег знања или природе дискурса. }\end{array}$} & \multirow{2}{*}{$\begin{array}{l}\text { типичан за формални } \\
\text { писани дискурс }\end{array}$} \\
\hline кад је речо & + & И & & \\
\hline e & + & И & $\begin{array}{l}\text { Примарно служи за дозивање, изражавање емотивног односа, } \\
\text { скретање саговорникове пажње, што може пратити и увођење } \\
\text { новог предмета; ретко се појављује као маркер промене пред- } \\
\text { мета без експресивне компоненте. }\end{array}$ & $\begin{array}{l}\text { искључиво у нефор- } \\
\text { малном разговору }\end{array}$ \\
\hline$e c a d(a)$ & + & И & $\begin{array}{l}\text { Примарно служи да уведе алтернативну аргументацију или } \\
\text { алтернативни развој догађаја; ретко се појављује као маркер } \\
\text { новог потпредмета без ове компоненте. }\end{array}$ & $\begin{array}{l}\text { типичан за разговор; у } \\
\text { писању доноси разго- } \\
\text { ворни и неформални } \\
\text { тон }\end{array}$ \\
\hline
\end{tabular}

Табела 1. Предметни конектори и њима блиски изрази. (Објашњење симбола: + - издвојен; $(+)$ - типично издвојен, али може остати укључен у структуру клаузе; И - иницијална позиција; П - постиницијална позиција; (П) - постиницијална позиција могућа, али ретка.) 


\section{3. Закључци}

Резултати које смо изнели упућују на неколико закључака. Најпре, предметни конектори се међу собом могу диференцирати према специфичности предмета који уводе. Неки предметни конектори, попут $а$ и него, општег су карактера - сигнализирају промену предмета независно од тога да ли је реч о потпредмету унутар истог ширег предмета, дигресији, преласку на потпуно нов предмет итд. Притом, и између ова два конектора постоје разлике, јер $a$ једнако уобичајено обележава и промену теме на плану информативне структуре реченице, што с конектором него није случај. За разлику од конектора $a$ и него, конектори иначе, узгред (буди речено) и елем специјализовани су за обележавање дигресије, при чему иначе и узгред (буди речено) уводе дигресију, док елем обележава њен крај и повратак на основни предмет.

Кад је реч о стилској одн. регистарској обележености предметних конектора, неки од њих карактеристични су пре свега за разговорни језик, а и кад се употребе у писању, тиме текст чине мање формалним и приближавају га говорењу; то важи за конекторе него и елем, као и за израз е сад (док је експресивна речца/узвик $е$ карактеристична само за разговорни језик). Други су пак регистарски неутрални ( $($, иначе и узгред (буди речено)). Конектора који би (искључиво или претежно) били одлика писаног језика нема, али постоје изрази што се тиче и кад је реч о, помоћу којих се образују конструкције које служе да уведу најављени или очекивани потпредмет и карактеристичне су за писани језик (в. одељак 2.6.1). Чињеница да нема општих предметних конектора специфичних за писани језика може се објаснити тиме да су у писаном језику аутору за сигнализирање нових (пот)предмета на располагању не само лексичка него и различита графичка, типографска средства (величина слова и типови слога којима се издвајају наслови, нумерација итд.), док у говореном језику таквих средстава нема.

Полифункционалност је упадљива одлика већине испитиваних израза. Заправо, једино се за конектор елем може рећи да му је основна (и једина?) функија да обележи промену предмета. Све друге јединице примарно имају неку другу граматичку, или граматичку и семантичку улогу: $a$ и него су напоредни везници који проширују своју употребу на домен текста (при чему $a$ у томе задржава своју основну функцију - као везник примарно обележава промену теме, а као конектор промену предмета, док него као везник такву функцију нема); узгред и иначе у основној употреби су део структуре клаузе и имају прилошку вредност. $E$ је узвик или експресивна речца, а спој е сад такође примарно има друге функције (уп. одељак 2.6.2). И за конструкције с изразима што се тиче и кад је реч о може се тврдити да примарно немају функцију конектора.

То значи да код већине конектора можемо говорити о њиховом развоју, тj. о процесу током ког се одређена јединица конвенционализује као конектор - од једне пунозначне речи попут прилога настају функционална реч попут конектора, или пак од једне функционалне речи као што је везник, настаје друга функционална реч - конектор. Питање за посебно истраживање је како 
тачно у ком случају овај процес конвенционализације (а у случајевима где је конектор примарно нека пунозначна реч може се говорити и о граматикализацији) изгледа. Ипак, и на основу наше анализе јасно је да постоје две кључне одлике којима се реч са неком другом функцијом конвенционализује у конекторској улози, а то су издвајање из структуре клаузе (тзв. парентетичка употреба) и (пост)иницијални положај. Од конектора испитиваних у овом раду, само иначе не мора бити синтаксички издвојен, што указује на то да процес граматикализације овог конектора није довршен.

\section{ИЗВОРИ}

PCXJ - S. Savić, V. Polovina, Razgovorni srpskohrvatski jezik, Novi Sad: Institut za južnoslovenske jezike, Filozofski fakultet, 1989.

Портал Растко - www.rastko.rs

Архива недељника Време - www.vreme.com

\section{ЛИТЕРАТУРА}

Велчић 1987: Mirna Velčić, Uvod u lingvistiku teksta, Zagreb: Školska knjiga.

Кликовац 2008: Душка Кликовац, „О семантици текстуалних конектора у српском језику који се састоје од предлога месног значења и поименичене заменице тај (поред тога, уз то, насупрот томе, поврх тога, при томе, према томе, иза тога, на то)", Зборник Матице српске за славистику, 71, 177-193.

Мишковић Луковић 2006: Mirjana Mišković Luković, Semantika i pragmatika iskaza. Markeri diskursa u engleskom jeziku, Beograd: Filološki fakultet.

Пипер 2001: Predrag Piper, Jezik i prostor, Beograd: Biblioteka XX vek.

Поповић 2004: Љубомир Поповић, Ред речи у реченици, Београд: Друштво за српски језик и књижевност Србије.

Поповић 2008: Љубомир Поповић, „Синтакса”, у: Ж. Станојчић и Љ. Поповић, Граматика српског језика, Београд: Завод за уџбенике, 204-384.

РСАНУ: Речник српскохрватског књижевног и народног језика, Београд: САНУ, 1957-.

Савић/Половина 1989: Svenka Savić i Vesna Polovina, Razgovorni srpskohrvatski jezik, Novi Sad: Institut za južnoslovenske jezike, Filozofski fakultet.

Танасић 2012: Срето Танасић, „Супротне реченице с везницима него и већ», у: Из синтаксе српске реченице, Београд: Београдска књига - Институт за српски језик САНУ, 166-180.

Фрејзер 1999: Bruce Fraser, „What are discourse markers?”, Journal of Pragmatics, 31, 931-952.

Фрејзер 2006: Bruce Fraser, „,Towards a theory of discourse markers”, y: K. Fischer (ed.), Approaches to Discourse Particles, Amsterdam: Elsevier, 189-205. 
Чудомировић 2009: Јован Чудомировић, „Речце као текстуални конектори у савременом српском језику”, Книжевност и језик, LVI, 3-4, 277-296.

Чудомировић 2015: Јован Чудомировић, Семантика и прагматика састав-

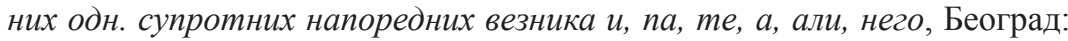
Филолошки факултет Универзитета у Београду, [необјављена докторска дисертација].

Шифрин 2003: Deborah Schiffrin, „Discourse markers: Language, meaning, and context", [у књизи] D. Schiffrin, D. Tannen and H. E. Hamilton (eds.), The Handbook of Discourse Analysis, Oxford: Blackwell, 54-76.

Jovan Čudomirović

ON DISCOURSE CONNECTIVES WHICH MARK TOPIC-CHANGE IN DISCOURSE

Summary

The paper deals with discourse connectives used to mark the change of topic (theme, discourse topic) and analyzes their syntactic properties and pragmatic functions using examples from both conversational corpus and written texts. Five different connectives (a, elem, inače, nego, uzgred (budi rečeno)) are analyzed, as well as some similar units (adpositions što se tiče and kad je reč o, interjection/particle $e$, connective $e$ sad). The concluding section discusses possible classification of these expressions and suggests topics for further research. 